\title{
Testing hypotheses on the ecological patterns of rarity using a novel model of study: snake communities worldwide
}

\author{
L. Luiselli
}

Luiselli, L. 2006. Testing hypotheses on the ecological patterns of rarity using a novel model of study: snake communities worldwide. - Web Ecol. 6: 44-58.

\begin{abstract}
The theoretical and empirical causes and consequences of rarity are of central importance for both ecological theory and conservation. It is not surprising that studies of the biology of rarity have grown tremendously during the past two decades, with particular emphasis on patterns observed in insects, birds, mammals, and plants. I analyse the patterns of the biology of rarity by using a novel model system: snake communities worldwide. I also test some of the main hypotheses that have been proposed to explain and predict rarity in species. I use two operational definitions for rarity in snakes: Rare species (RAR) are those that accounted for $1 \%$ to $2 \%$ of the total number of individuals captured within a given community; Very rare species (VER) account for $\leq 1 \%$ of individuals captured. I analyse each community by sample size, species richness, continent, climatic region, habitat and ecological characteristics of the RAR and VER species. Positive correlations between total species number and the fraction of RAR and VER species and between sample size and rare species in general were found. As shown in previous insect studies, there is a clear trend for the percentage of RAR and VER snake species to increase in species-rich, tropical African and South American communities. This study also shows that rare species are particularly common in the tropics, although habitat type did not influence the frequency of RAR and VER species. This analysis also confirms the commonly accepted ecological hypothesis that body size and rarity are clearly and widely correlated in natural animal communities. However, in snake communities there is often an association between large and small species among the rare species, and a tendency for ophiophagous species to be rare. In addition, there was no support for the hypothesis that rare species should be typically phylogenetically primitive. The hypothesis that species with narrower realized ecological niches are more likely to be rare or very rare is supported by the evidence presented here on snake communities. In general, this study shows that snakes may make "model organisms" for studies on the biology of rarity.
\end{abstract}

L. Luiselli (lucamlu@tin.it), F.I.Z.V. (Ecology) and Centre of Environmental Studies 'Demetra s.r.l.', via Olona 7, I-00198 Roma, Italy.

Because of its wide conceptual and practical application, the study of the biology of rarity has received tremendous attention in the past two decades, resulting in several important papers and books (Schoener 1987, Gaston 1994, Blackburn and Gaston 1997, 1999). Theoretical advancement on the biology of rarity has been due primarily to research on insects (Morse et al. 1988, Novotny 1993, 1995, Price et al. 1995, Ulrich 2001a, b), endothermic vertebrates (i.e., birds, Cotgreave and Pagel 1997, and mammals, Yu and Dobson 2000, Harcourt et al. 2002), and plants (Rabinowitz 1981). Such studies are very rare on ectothermic vertebrates (for an exception, Wilcove et al. 
1998), even though ectothermic vertebrates in general, and snakes in particular, have become "model organisms" for ecological studies in recent years (Shine and Bonnet 2000, Luiselli 2006a, b for recent reviews). In this paper, snakes are used as a novel model system to explore and test some of the main hypotheses and predictions on rarity in natural communities of animals. Herein I ask the following questions on the biology of rarity to snakes:

(1) Does species distribution show geographical bias (Schoener 1987)? Are rare species more prevalent in the tropics vs. temperate regions (Morse et al. 1988, Novotny 1993, Stork et al. 1997)?

(2) Because snakes are carnivorous predators (Luiselli 2006a) and large predators are usually scarcer than small predators (Cotgreave 1993, Blackburn and Gaston 1999, Spencer 2000), are rare snakes more likely to be among the larger species in the community? A correlation between rarity and large body size was indeed suggested by earlier studies (Gaston 1994, Blackburn and Gaston 1997).

(3) Are rare snake species characterized by narrow realized ecological niches and high degrees of specialization (Gaston 1996, Gaston and Curnutt 1998)?

(4) Do rare species typically belong to phylogenetically old and/or primitive taxa (Cotgreave and Pagel 1997)? That is: are some phylogenetically primitive families overrepresented in the samples of rare species?

Other hypotheses related to rarity, such as rare species more often have drastic, chaotic density fluctuations and limited dispersal abilities (Vandermeer 1982), are not tested here because there is presently insufficient knowledge on snake ecology and life history to reasonably test these hypotheses.

\section{Materials and methods}

Data come from an extensive review of the literature and include published studies on the community composition of snakes worldwide from peer-reviewed journals and academic/technical dissertations (Luiselli 2006b). I have also used personal unpublished data where applicable. I selected only studies that furnish re-analysable raw data, and from this group, selected studies that provide a dataset inclusive of all snake species sampled at a given study area. Consequently, excluded from this analysis are studies that focus on a particular subset of species, such as those taxonomically organized (sympatric species of a given family) or organized by guild (aquatic, arboreal, etc.) (Seigel et al. 1995). Short term studies lasting fewer than one year were excluded because snakes are generally elusive (Greene 2001) and prone to demographic fluctuations due to external factors such as prey availability or drought (Andrén and Nilson 1983, Seigel et al. 1995). Short-term studies are likely to underestimate the presence and frequency of elusive or rare species (Gibbons et al. 1997, Fitch 1999), so variation in the numbers observed may reflect sampling biases and not true patterns. Thus, only studies lasting at least two years were used for our analyses. Other studies considered inappropriate for this analysis include those (i) whose authors openly declared potential sampling biases toward specific snake guilds or species, (ii) in which data for only some species of the community are given (Marques et al. 2001), and (iii) based merely on lists of specimens from a locality as available in museum collections. With regard to item iii, it is unclear if all the encountered specimens were collected, hence the variation in abundance among species may be dubiously depicted. Because of the strict selection criteria, just 35 community studies were analyzed out of 163 initially assessed.

One of the major difficulties in evaluating rarity is that there is no widely accepted definition, and the issue is even controversial (Gaston 1994, Kunin and Gaston 1997, Ulrich 2001a, Harcourt et al. 2002). For example, a species may be naturally rare in a given community because the area surveyed is on the outskirts of its natural range (this is typical with species that are common globally, but that are locally rare; Harcourt et al. 2002); rarity might also be more of a result of human impact (i.e., over-hunting; one species preferred over another or due to cultural beliefs), vs. ecological factors. Additionally, the capture method used, the behavior of the species (not all the species are equally cryptic), time of sampling (i.e., season or time of day), and the size of the species may affect capture rate (Luiselli 2006 c for a precise case study with snakes), and so result in a greater likelihood of capture of one species over another. This may be relevant in these studies and thus worthy of note. I define rarity in terms of relative percent of occurrence of species within random samples of snakes in a community, assuming that rare species (i.e., species with low relative density) should occur at least occasionally during sampling. In a meta-analysis such as this, this is the only practical criterion that can be used with snakes because snakes are too elusive to establish with any confidence, for every species in a community, population density (Filippi 1995, Luiselli 2006c). Operatively, I define "rare species" (RAR) as those that occur with a frequency of $1.01 \%$ to $2 \%$ of the total number of observed individuals in a given community. "Very rare species" (VER) are those that occur with a frequency of $\leq 1 \%$. Only snake communities in which at least 50 different individuals were captured are included in this study. In a few cases (Table 1), the number (and relative proportion of occurrence) of VER species was incalculable because the $1 \%$ criterion was not satisfied (i.e., sample sizes were too small). In these cases, I only considered the number of RAR species (those satisfying the $1 \%$ to $2 \%$ criterion) for analysis. Overall, my definition of rare species is similar to that of McDonald and Thompson (2004), where rare populations are defined, from a statistical sampling viewpoint, as those with a low probability of detection, because they occur in low numbers, are cryptic, or have a clumped distribution over wide areas. 
Although this study is based on research conducted worldwide and in a wide variety of environments (Table $1)$, there is disproportionately more studies from certain countries, such as the USA and Italy, where researchers have traditionally given greater attention to snake community ecology. Therefore, it is possible that some of the conclusions might be influenced by the relative weight of datasets from these countries. Nonetheless, this potential bias could not be ascertained given the present state of knowledge on snake communities; further studies from a wider range of countries are needed.

\section{Statistical analyses}

Two variables were compared using Spearman's nonparametric correlations. One-way Analysis of Variance (ANOVA) was used to assess means and dispersion measures with multiple comparisons; when appropriate, Tukey's HSD post-hoc test was used to assess "direction" of the ANOVA comparisons. In order to test whether some snake families were over- or under-represented in the RAR and VER species samples, I compared the relative frequency of the various families in RAR and VER with their expected frequency calculated by the absolute number of species per family, and used observed vs. expected $\chi^{2}$ as statistical test. The number of described species for each family is given in Halliday and Adler (2002). All statistical tests were performed by SPSS (version 11.0 for Windows), with all tests being two-tailed and alpha set at 5\%.

\section{Results and discussion}

\section{Broad patterns of rarity in snakes}

Raw data are summarized in Table 1. Overall, there is a significant negative correlation between sample size (number of individual snakes captured at each site) and the percentage of RAR species ( $r s=-0.377, n=35, p<0.05$ ) and a non-significant correlation between sample size and the percentage of VER species ( $\mathrm{rs}=0.333, \mathrm{n}=29, \mathrm{p}=$ 0.078 ). The number of species present at each site, or species richness, was correlated with the absolute number and relative proportion of occurrence of rare species. The absolute numbers of both RAR and VER species were significantly and positively correlated to species richness (RAR, $\mathrm{rs}=0.869, \mathrm{n}=35, \mathrm{p}<0.01$; VER, $\mathrm{rs}=0.893, \mathrm{n}=29, \mathrm{p}<$ 0.01 ; Figs. $1 \mathrm{a}$ and $1 \mathrm{~b}$ ). A positive correlation was also present between species richness and percentage of RAR species ( $\mathrm{rs}=0.711, \mathrm{n}=35, \mathrm{p}<0.01$ ) and percentage of VER species ( $r s=0.717, \mathrm{n}=29, \mathrm{p}<0.01$; Figs. $1 \mathrm{c}$ and $1 \mathrm{~d}$ ). The number of RAR species and percentage of RAR species (\%RAR) were significantly correlated ( $\mathrm{rs}=0.937, \mathrm{n}=$ $35, \mathrm{p}<0.01)$, as was the number of VER species and per- centage of VER species (\%VER) ( $\mathrm{rs}=0.936, \mathrm{n}=29, \mathrm{p}<$ 0.01 ), so only \%RAR and \%VER species were used in the following analyses.

This positive correlation between total species number and the fraction of RAR and VER species mirrors evidence presented by Novotny and Basset (2000), who reported a similar relationship between fractions of singletons (species represented by a single individual in a sample) and species richness in leaf-chewing insect communities. However, this relationship has been not observed in other study systems of insects (Ulrich 2001a). Novotny and Basset (2000) observed a significant correlation between sample size and the fraction of singletons, which is again similar to the results presented here, but where RAR and VER fractions are considered instead of singletons. In this study case, the result may be in part a statistical artefact dependent on the fact that I considered arbitrary percent frequency values for RAR and VER. Thus, the total number of rare species necessarily increases with increasing species richness, and this may in turn increase the proportion of rare species. For example, if we take a community following a canonical lognormal distribution, for ten species about four will account for less than $1 \%$ of total count, and in a community of 50 species 38 will have a frequency of less than 0.01 and for 100 species 86 (these values were estimated by computing 100 communities each). Thus, the frequency of rare species may apparently increase although all communities have identical structure. The example is also similar to the concerns of Nee et al (2005) on the illusion of biological invariants.

\section{Are there geographical biases in the distribution of species? Are there more rare species in the tropics than in the temperate regions?}

The percentage of RAR species was significantly different among continents (one-way ANOVA, $\mathrm{F}_{5,34}=4.922, \mathrm{p}<$ 0.002 ), being much higher in Africa and South America than in Europe and North America (Tukey post-hoc test, $\mathrm{p}$ $<0.01$, after excluding Australia and Asia because each had only one study; Fig. 2a). The percentage of VER species was also significantly different among continents (one-way ANOVA, $\left.\mathrm{F}_{4.28}=5.021, \mathrm{p}<0.004\right)$, being much higher in South America (Tukey post-hoc, $\mathrm{p}<0.01$ ). Both percentages of RAR species $\left(\mathrm{F}_{1,34}=19.256, \mathrm{p}<0.0001\right)$ and VER species $\left(\mathrm{F}_{1,28}=8.085, \mathrm{p}<0.008\right)$ were significantly higher in tropical than in temperate areas. Habitat type did not affect \%RAR $\left(\mathrm{F}_{7,34}=0.621, \mathrm{p}=0.732\right)$ or $\% \operatorname{VER}\left(\mathrm{F}_{7,28}=\right.$ $1.198, \mathrm{p}=0.365)$; also the interaction habitat $\times$ continent was not significant on \%RAR $\left(\mathrm{F}_{334}=1.275, \mathrm{p}=0.311\right)$ or on \%VER $\left(\mathrm{F}_{3.28}=1.816, \mathrm{p}=0.191\right)$.

Overall, this study demonstrates consistent trends regarding the percentage of RAR and VER species (i.e., the frequency of rarity): These species are more likely to occur 
Table 1. Summarized dataset used for this study, including study area, sample sizes, number and relative percentage of rare (RAR) and very rare (VER) species, habitat type, country, continent, and pertinent literature entry. Note that habitat types are simplified for allowing comparisons between areas; for instance, all prairie-like grasslands are considered 'savannah', all types of swamped areas are considered 'wetlands', etc.

\begin{tabular}{|c|c|c|c|c|c|c|c|c|}
\hline $\begin{array}{l}\text { Study area } \\
\text { (reference) }\end{array}$ & $\begin{array}{r}\text { Sample size } \\
\text { (and no. } \\
\text { species) }\end{array}$ & $\begin{array}{r}\text { No } \\
\text { RAR }\end{array}$ & $\begin{array}{r}\text { No } \\
\text { VER }\end{array}$ & $\begin{array}{r}\% \\
\text { RAR }\end{array}$ & $\begin{array}{r}\% \\
\text { VER }\end{array}$ & Habitat type & Region & Continent \\
\hline $\begin{array}{l}\text { Monterano } \\
\text { (Filippi and }\end{array}$ & & & & & & & & \\
\hline $\begin{array}{l}\text { Luiselli 2006) } \\
\text { Eket (Luiselli }\end{array}$ & $537(8)$ & 1 & 1 & 12.5 & 12.5 & Maquis & Italy & Europe \\
\hline $\begin{array}{l}\text { et al. 2005) } \\
\text { Port Harcourt } \\
\text { (Luiselli and }\end{array}$ & $137(24)$ & 5 & 3 & 20.8 & 12.5 & Forest & Nigeria & Africa \\
\hline $\begin{array}{l}\text { Akani 2002) } \\
\text { Ejule (Akani }\end{array}$ & $167(17)$ & 2 & $\begin{array}{r}1 \\
\text { not }\end{array}$ & 11.8 & $\begin{array}{l}5.9 \\
\text { not }\end{array}$ & Mangroves & Nigeria & Africa \\
\hline $\begin{array}{l}\text { et al. 1999) } \\
\text { Tengchih }\end{array}$ & 77 (18) & 3 & $\begin{array}{r}\text { calculable } \\
\text { not }\end{array}$ & 16.7 & $\begin{array}{r}\text { calculable } \\
\text { not }\end{array}$ & Savannah & Nigeria & Africa \\
\hline $\begin{array}{l}\text { (Lee 2005) } \\
\text { Big Sandy }\end{array}$ & $69(16)$ & 3 & calculable & 18.7 & calculable & Forest & Taiwan & Asia \\
\hline $\begin{array}{l}\text { Creek (Lewis } \\
\text { et al. 2000) } \\
\text { Sheff's Wood }\end{array}$ & $63(12)$ & 1 & $\begin{array}{r}\text { not } \\
\text { calculable }\end{array}$ & 8.33 & $\begin{array}{r}\text { not } \\
\text { calculable }\end{array}$ & Forest & USA & $\begin{array}{l}\text { North } \\
\text { America }\end{array}$ \\
\hline $\begin{array}{l}\text { (Ford et al. } \\
\text { 1991) } \\
\text { Caddo Lake }\end{array}$ & $142(15)$ & 3 & 2 & 20 & 13.3 & Forest & USA & $\begin{array}{l}\text { North } \\
\text { America }\end{array}$ \\
\hline $\begin{array}{l}\text { (Fleet and } \\
\text { Audrey 1999) }\end{array}$ & $251(13)$ & 3 & 0 & 23.1 & 0 & Forest & USA & $\begin{array}{l}\text { North } \\
\text { America }\end{array}$ \\
\hline $\begin{array}{l}\text { Marcigliana } \\
\text { (Capizzi et al. } \\
\text { 1995) }\end{array}$ & $448(5)$ & 0 & 0 & 0 & 0 & Agricultural & Italy & Europe \\
\hline $\begin{array}{l}\text { Sella Nevea } \\
\text { (Luiselli 2006) } \\
\text { Kansas Univ. }\end{array}$ & $340(3)$ & 0 & 0 & 0 & 0 & $\begin{array}{l}\text { Mountain } \\
\text { grassland }\end{array}$ & Italy & Europe \\
\hline $\begin{array}{l}\text { Reservoire } \\
\text { (Fitch 1982) } \\
\text { Chihuahua }\end{array}$ & $22093(12)$ & 0 & 6 & 0 & 50 & Savannah & USA & $\begin{array}{l}\text { North } \\
\text { America }\end{array}$ \\
\hline $\begin{array}{l}\text { (Reynolds et al. } \\
\text { 1982) }\end{array}$ & $418(20)$ & 2 & 7 & 10 & 35 & Desert & Mexico & $\begin{array}{l}\text { North } \\
\text { America }\end{array}$ \\
\hline $\begin{array}{l}\text { Dielmo (Trape } \\
\text { and Mane 2000) } \\
\text { Duchessa Mt }\end{array}$ & $1256(28)$ & 7 & 15 & 25 & 53.6 & Savannah & Senegal & Africa \\
\hline $\begin{array}{l}\text { (Filippi and } \\
\text { Luiselli 2000) } \\
\text { Rota (Filippi }\end{array}$ & $84(6)$ & 0 & $\begin{array}{r}\text { not } \\
\text { calculable }\end{array}$ & 0 & $\begin{array}{r}\text { not } \\
\text { calculable }\end{array}$ & $\begin{array}{l}\text { Mountain } \\
\text { grassland }\end{array}$ & Italy & Europe \\
\hline 1995) & $860(6)$ & 0 & 0 & 0 & 0 & Maquis & Italy & Europe \\
\hline $\begin{array}{l}\text { Calabar (Butler } \\
\text { and Reid 1986) } \\
\text { Clark Fork }\end{array}$ & $127(34)$ & 5 & 13 & 14.7 & 38.2 & Forest & Nigeria & Africa \\
\hline $\begin{array}{l}\text { Valley (Boundy } \\
\text { 2001) } \\
\text { Little Karoo }\end{array}$ & $170(6)$ & 0 & 0 & 0 & 0 & Wetland & USA & $\begin{array}{l}\text { North } \\
\text { America }\end{array}$ \\
\hline (Branch and & & & not & & not & & South & \\
\hline $\begin{array}{l}\text { Bauer 1995) } \\
\text { Rondonia (da }\end{array}$ & $66(17)$ & 4 & calculable & 23.5 & calculable & Savannah & Africa & $\begin{array}{l}\text { Africa } \\
\text { South }\end{array}$ \\
\hline $\begin{array}{l}\text { Silva 1993) } \\
\text { Oriolo Romano } \\
\text { (Luiselli et al. }\end{array}$ & $1016(68)$ & 10 & 49 & 14.7 & 72 & Forest & Brazil & America \\
\hline
\end{tabular}


Table 1. Continued.

\begin{tabular}{|c|c|c|c|c|c|c|c|c|}
\hline $\begin{array}{l}\text { Study area } \\
\text { (reference) }\end{array}$ & $\begin{array}{r}\text { Sample size } \\
\text { (and no. } \\
\text { species) }\end{array}$ & $\begin{array}{r}\text { No } \\
\text { RAR }\end{array}$ & $\begin{array}{r}\text { No } \\
\text { VER }\end{array}$ & $\begin{array}{r}\% \\
\text { RAR }\end{array}$ & $\begin{array}{r}\% \\
\text { VER }\end{array}$ & Habitat type & Region & Continent \\
\hline $\begin{array}{l}\text { Rome (Rugiero } \\
\text { 2004) } \\
\text { El Bagual }\end{array}$ & $171(4)$ & 0 & 0 & 0 & 0 & Agricultural & Italy & Europe \\
\hline $\begin{array}{l}\text { (Yanosky } \\
\text { et al. 1996) } \\
\text { Hernando }\end{array}$ & $344(33)$ & 1 & 13 & 3 & 39.4 & Wetland & Argentina & $\begin{array}{l}\text { South } \\
\text { America }\end{array}$ \\
\hline $\begin{array}{l}\text { (Enge and } \\
\text { Wood 2000) } \\
\text { Great Basin }\end{array}$ & $478(23)$ & 4 & 9 & 17.4 & 39.1 & Wetland & USA & $\begin{array}{l}\text { North } \\
\text { America }\end{array}$ \\
\hline $\begin{array}{l}\text { Desert (Brown } \\
\text { and Parker } \\
\text { 1982) }\end{array}$ & $1122(5)$ & 0 & 1 & 0 & 20 & Desert & USA & $\begin{array}{l}\text { North } \\
\text { America }\end{array}$ \\
\hline $\begin{array}{l}\text { Armidale } \\
\text { (Shine 1977) }\end{array}$ & $720(9)$ & 0 & 2 & 0 & 222 & Wetland & Australia & Australia \\
\hline Amazzonico & $/ 20(9)$ & 0 & 2 & 0 & 22.2 & Wetland & Australıa & Australıa \\
\hline $\begin{array}{l}\text { (Duellmann } \\
\text { 2005) }\end{array}$ & $360(46)$ & 11 & 22 & 23.9 & 47.8 & Forest & Brazil & $\begin{array}{l}\text { South } \\
\text { America }\end{array}$ \\
\hline $\begin{array}{l}\text { Cotonou } \\
\text { (Inyang 2005) }\end{array}$ & $184(14)$ & 3 & 3 & 21.4 & 21.4 & Savannah & Benin & Africa \\
\hline $\begin{array}{l}\text { Lekki Lagoon } \\
\text { (Inyang 2005) }\end{array}$ & $215(17)$ & 1 & 3 & 5.9 & 17.6 & Wetland & Nigeria & Africa \\
\hline $\begin{array}{l}\text { Uyo (Eniang } \\
\text { et al. 2002) }\end{array}$ & $57(18)$ & 7 & $\begin{array}{r}\text { not } \\
\text { calculable }\end{array}$ & 38.9 & $\begin{array}{r}\text { not } \\
\text { calculable }\end{array}$ & Agricultural & Nigeria & Africa \\
\hline $\begin{array}{l}\text { Yenagoa (Akani } \\
\text { et al. 2002) } \\
\text { Sierra Nevada }\end{array}$ & $111(17)$ & 2 & 3 & 11.8 & 17.6 & Agricultural & Nigeria & Africa \\
\hline (Block and & & & & & & & & North \\
\hline $\begin{array}{l}\text { Morrison 1998) } \\
\text { Konza Prairie }\end{array}$ & $190(5)$ & 0 & 0 & 0 & 0 & Forest & USA & $\begin{array}{l}\text { America } \\
\text { North }\end{array}$ \\
\hline $\begin{array}{l}\text { (Cavitt 2000) } \\
\text { Tolfa Mt }\end{array}$ & $550(10)$ & 1 & 3 & 10 & 30 & Savannah & USA & America \\
\hline $\begin{array}{l}\text { (Filippi 2003) } \\
\text { Mabula-Rojberg }\end{array}$ & $575(5)$ & 0 & 1 & 0 & 20 & Maquis & Italy & Europe \\
\hline $\begin{array}{l}\text { (Schmidt and } \\
\text { Olsen 1998) } \\
\text { Langjan }\end{array}$ & $169(27)$ & 8 & 9 & 33.3 & 29.6 & Savannah & $\begin{array}{l}\text { South } \\
\text { Africa } \\
\text { South }\end{array}$ & Africa \\
\hline (Schmidt 2002) & $109(17)$ & 5 & 4 & 29.4 & 23.5 & Savannah & Africa & Africa \\
\hline
\end{tabular}

in species-rich, tropical African and South American snake communities. Other studies have found that high percentages of singletons are more common in surveys conducted in the tropics (Schoener 1987, Morse et al. 1988, Novotny 1993, Stork et al. 1997, Ulrich 2001a). Although this study does not focus on singletons, but instead on relative measures of rare species, the conclusions drawn here are congruent with those of the above-mentioned previous research. It is possible that differences between tropical and non-tropical regions (which also show continental differences in this study) are the result of lower absolute densities of several tropical species (Schoener 1987, Price et al. 1995, Ulrich 2001a), or that the higher frequency of rarity in the tropics may depend on different patterns of resource distribution and niche apportionment in snake communities (Hughes 1986, Tokeshi 1990, 1996, Bersier and Sugihara 1997, Kunin and Gaston 1997, Moulliot et al. 2000, Novotny and Basset 2000, Ulrich 2001b, Johansson et al. 2006). However, as the operational definition of rarity used in this paper (as well as in many equivalent studies) may influence the frequency results, it may also influence the latitudinal gradient and continental differences we detected because these differences are strongly connected with differences in total species richness. In any case, snakes may be useful models for further analyses on the theme of rarity in tropical vs. temperate regions, and I strongly encourage scientists to give attention to this noteworthy issue. 


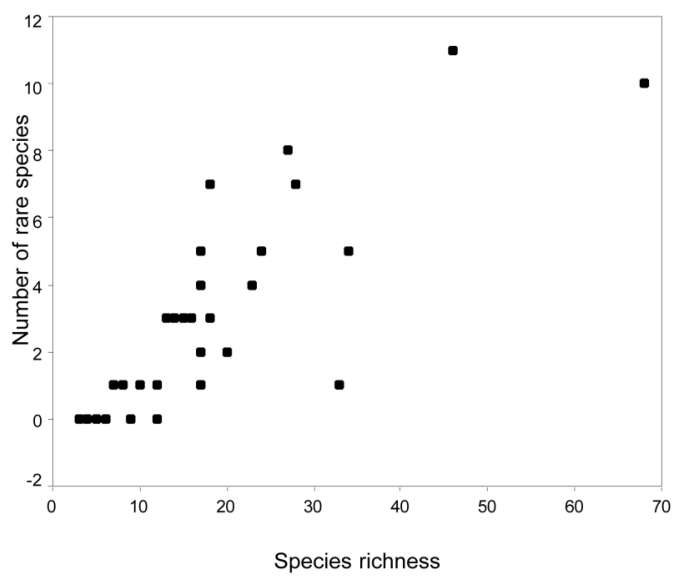

(c)

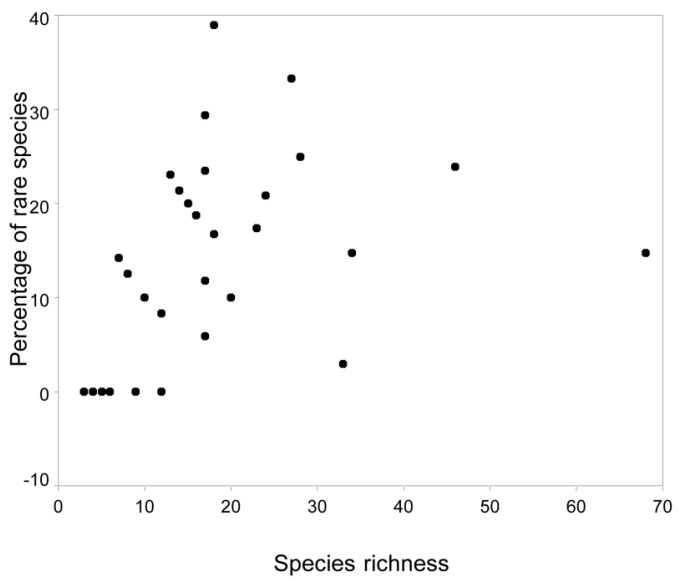

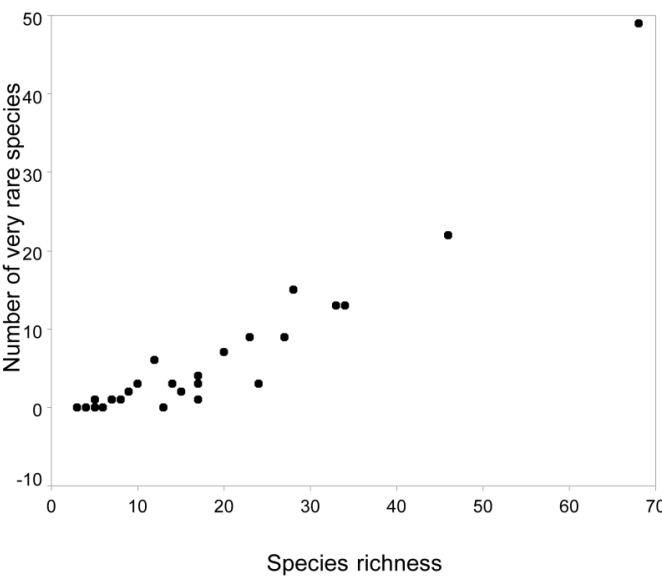

(d)

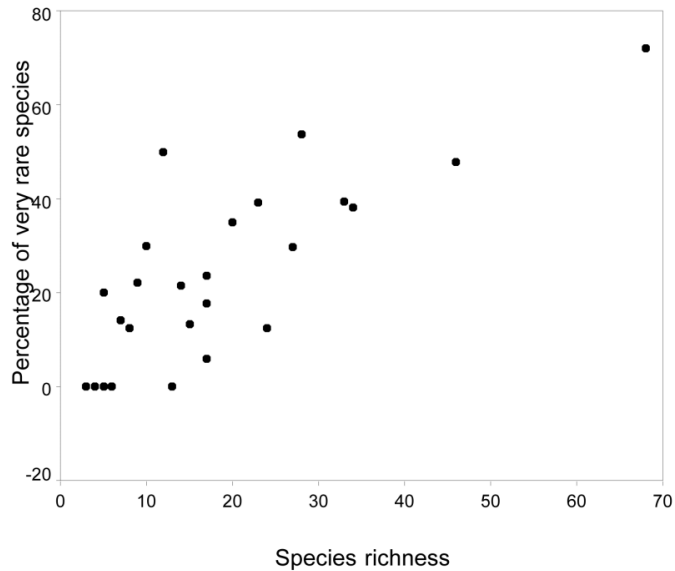

Fig. 1. Correlation between species richness and number of rare species (graphic a), number of very rare species (graphic b), percentage of rare species (graphic c), and percentage of very rare species (graphic d), in snake communities throughout the world.

\section{Are rare species of snakes characterized by larger body size?}

If rarity in snakes is positively associated with large body size, we should expect the largest species in a community (for instance, Elaphe quatuorlineata in Mediterranean assemblages, or the larger pythons, anacondas, and boas in the tropics) should commonly appear among the RAR and VER species. Once RAR and VER species were pooled in the analyses (Appendix 1 for a list of species by locality), disproportionately larger species were associated with RAR or VER in $35.7 \%$ of the study areas. Comparing these observed values with random draws of species among sizes generated by $3 \times 10^{4}$ Monte Carlo simulations, it resulted that the observed value was significantly larger $(\mathrm{p}<0.01$ at $\chi^{2}$ test) than those randomised. However, in several cases the presence of large species in the RAR or VER categories was also associated with the presence of several smallersized species. For instance, at a Senegalese savannah locality, the presence of the giant rock python (Python sebae) was accompanied by very small Typhlops, Leptotyphlops, and Crotaphopeltis species in the RAR/VER groups, and at one Mediterranean forest locality (Oriolo Romano) the occurrence of the large-sized Elaphe quatuorlineata as VER was accompanied with that of Coronella austriaca, the smallest snake of the area, as RAR (Appendix 1). Therefore, overall this data does support the prediction that rarity is typically correlated with large body size, in agreement with Gaston (1994) and Blackburn and Gaston (1997) arguing that large body size is the only clearly established pattern in biology of rarity studies. However, in snakes these patterns are more complicated and often reveal asso- 
(a)

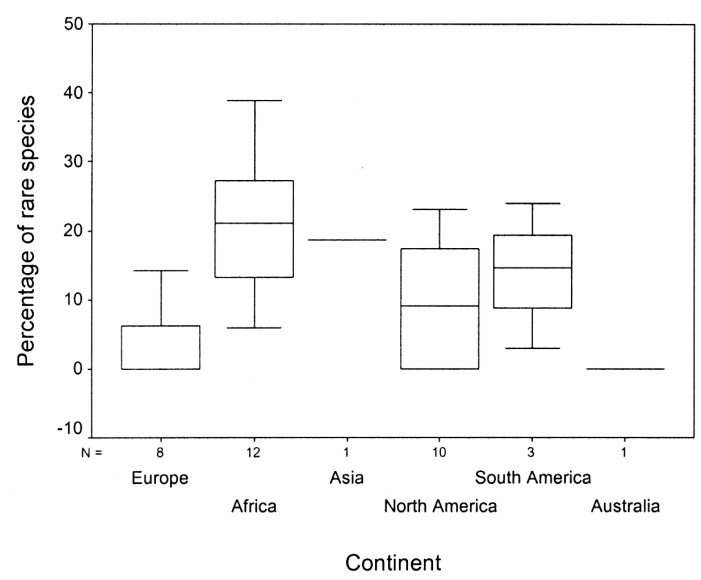

(b)

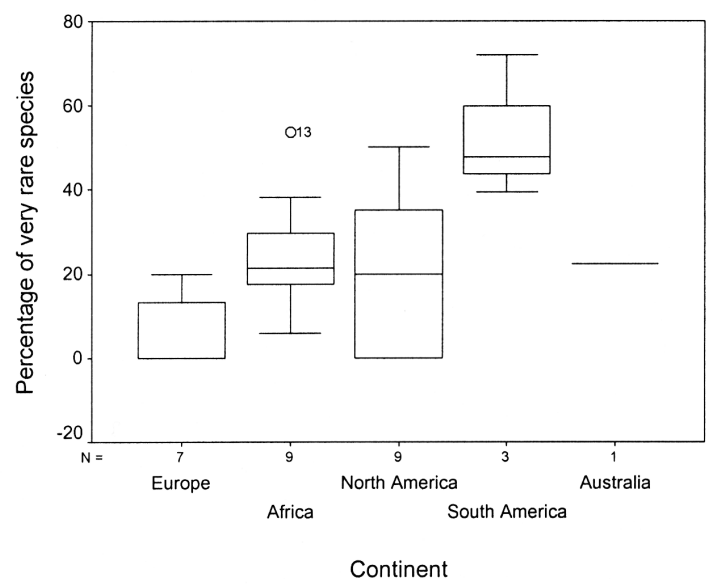

Fig. 2. Intercontinental variation in the percentage of rare species (graphic a) and of very rare species (graphic b) in snake communities throughout the world. Box and whiskers show mean, standard deviation and standard error. The outlier in graphic $b$ (13), is a Senegal savannah locality (Appendix 1 for more details). $\mathrm{N}=$ number of communities.

ciations of very large and very small species among the rare species within communities. I suspect that the reason the small size snakes were rare, along with the predicted rarity of large snakes, is due to the generally secretive nature of small snakes. This is important to mention because assuming that the number of detections is an index of rarity may be biased by some cases of true rarity (low numbers of individuals) for the large snakes and low detection probability with the small snakes.

The fact that in several snake communities there is no evident correlation between absolute body size and rarity may be explained because, as ectotherms, most snake species consume relatively little biomass; if prey availability is one factor that limits the abundance of large endothermic carnivores we might in fact not expect the abundance of large snakes to be limited in the same way. This would be a very interesting finding indeed, and certainly this hypothesis needs further exploration.

\section{Are rare snake species characterized by narrow realized ecological niches and high degrees of specialization?}

To answer to this question, it is necessary to focus on snake communities constituted by species that are relatively well known in ecological terms. I therefore must exclude the species-rich communities of tropical South America (because the ecology of its various species is nearly unknown) and instead focus attention on the communities from Mediterranean Europe, Australia, tropical Africa, and North America, where species have been well researched during the past few decades (Luiselli 2006a and 2006b).

In the Mediterranean communities, the smaller-sized colubrids of the genus Coronella are the only species with a narrow realized niche, having strictly selective habitat requirements (at least in Mediterranean regions, Bruno and Maugeri 1990, Filippi and Luiselli 2006), including being nocturnal and semi-fossorial (Agrimi and Luiselli 1994) and dietary specialists (feeding primarily on lizards, with less than $7 \%$ of their diet varying among populations, Luiselli 2006a). Thus, it was not surprising that species in this genus were considered RAR or VER in all of the study areas where they were found (Appendix 1). In the Australian study case (Shine 1977), although there were no RAR species, two VER species were identified: 1) Cryptophis nigrescens, a moderate-sized, fossorial, and nocturnal (hence difficult to detect) snake that feeds mainly on diurnal scincid lizards at night when the lizards are sleeping (but also on mammals and even other snakes, Shine 1984), and 2) Vermicella annulata, also fossorial and a dietary specialist (Shine 1980, 1993).

In tropical African rainforests and savannahs, several species have narrow niches, such as the obligate egg-eaters of the genus Dasypeltis (Chippaux 1999), the snake-eaters of the genus Mehelya (Shine et al. 1996), and the morphologically specialized burrowers of the genera Atractaspis, Typhlops, Rhinotyphlops, and Aparallactus (Luiselli et al. 1998, Shine et al. 2006). These species were regularly present among the RAR and VER species at each African site, although almost invariably together with several species that do not exhibit obvious specialization characters. However, it should also be mentioned that these African genera are burrowing, and thus they may appear rarer than they actually are just because their sampling is difficult in the field. With regard to North America, there are less obvious patterns of ecological characteristics of rare snake species, although some genera (Farancia, Heterodon, Lampropeltis, Storeria, etc.) were frequently observed among 


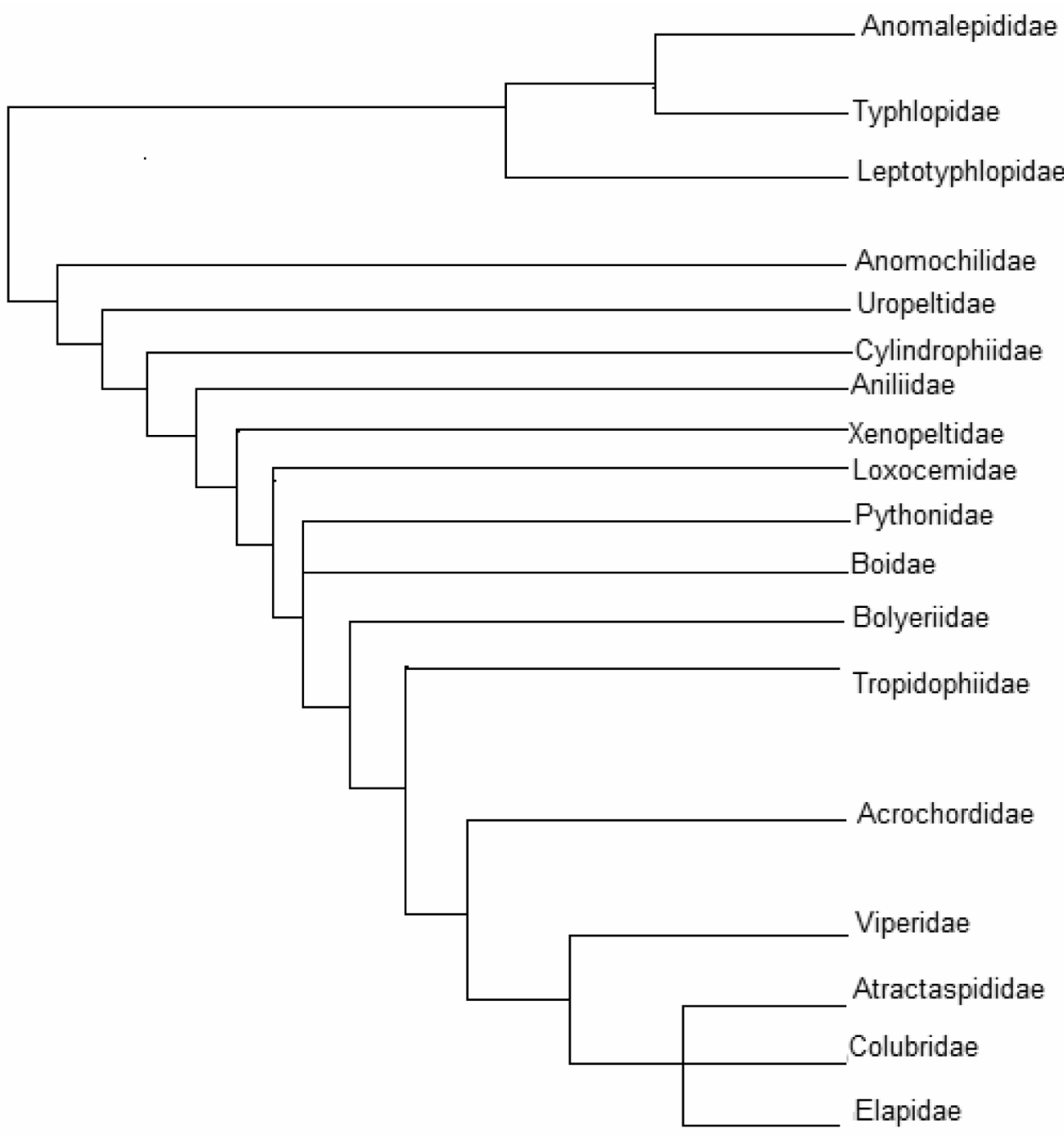

Fig. 3. Phylogenetic tree showing the relationships among the 18 families of snakes (re-drawn from Halliday and Adler 2002). Overall, primitive groups are upper-right of the graphic, and advanced groups are lower-right of the graphic.

RAR and VER species (Appendix 1). These species, however, are often food generalists and hence the pattern in North America is not in agreement with data from other continents.

There are several obligate or nearly-obligate ophiophages among snakes (for instance, the king cobra Ophiophagus hannah, several colubrids including the mussurana Clelia clelia, etc), and I would expect there to be a very direct link between ophiophagy and rarity in a snake community. Unfortunately, the available data are too scarce to investigate this potentially relevant subject. However, some of the species which feed frequently on other snakes (for instance, the African file snakes of the genus Mehelya and the stiletto snakes of the genus Atractaspis, and the south-American
Clelia) appeared frequently among RAR or VER species (Appendix 1). This evidence may strengthen the hypothesis of a link between ophiophagy and rarity in snakes, but we definitely need more data for a final conclusion on this issue.

Overall, on the basis of the above-mentioned arguments, we may predict some of the ecological characteristics of rare snake species: Species having narrow ecological niches, especially if they are small-sized, fossorial, and/or dietary specialists, are more suspectible to rarity. Thus, I predict that further studies will generally show that snakes with the above-mentioned ecological characteristics are more likely to be rare in the natural communities of these organisms, this fact being independent of continent, habitat, or climatic region. 


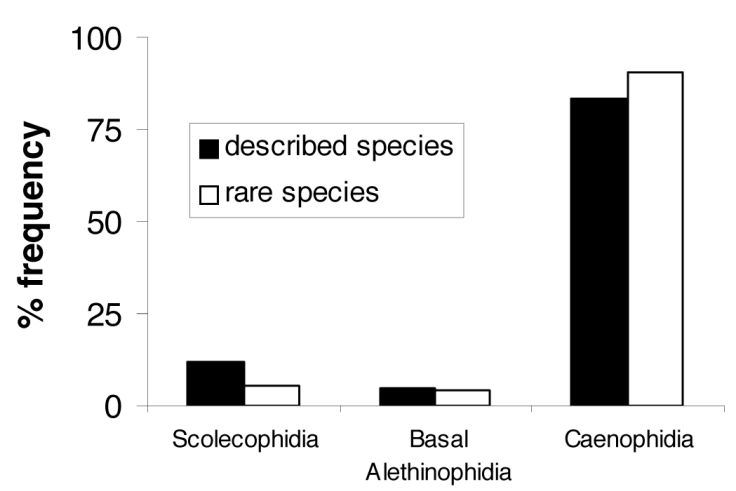

Snake taxonomic group

Fig. 4. Comparison between the percent frequency of occurrence of rare species $(R A R+V E R)$ in the reviewed literature (total $n=$ 206) and the percentage of known species classified by family in relation to the total number of snake species $(n=2718)$, in the three broad taxonomic groups of snakes. Subdivision of snake families by broad taxonomic group follows Table 2 . For the statistical details see the text.

\section{Do rare species typically belong to phylogenetically old and/or primitive taxa?}

If Cotgreave and Pagel's (1997) hypothesis that rare species should be mainly those phylogenetically old/primitive is correct, we should expect that phylogenetically primitive families of snakes are over-represented in the samples of rare species. I used the phylogenetic tree given in Fig. 3 (redrawn from Halliday and Adler 2002) to subdivide the various snake families into phylogenetically primitive (Scolecophidia), intermediate (basal Alethinophidia) or advanced snakes (Caenophidia), and compared the observed and expected number of rare species by taking into consideration the relative number of species described for each family across the world (Table 2). Overall, 206 different species of snakes were listed as RAR or VER in the various study areas (Appendix 1 for a catalogue of the species names divided by locality). The observed distribution of rare species by family did not differ significantly from expected $\left(\chi^{2}=16.2, \mathrm{DF}=17, \mathrm{p}=0.511\right)$, and the same was true also when pooling the various families according to their broad group $\left(\chi^{2}=4.15, \mathrm{DF}=2, \mathrm{p}=0.125\right.$; Fig. 4).

Table 2. Absolute numbers and relative frequency of occurrence (\%) of rare species (RAR + VER) divided by family, as found in the studies reviewed in this article, and compared to the absolute numbers of known species (and their relative \% frequency of occurrence) of the corresponding family throughout the world. Data on the numbers of world's described species divided by family came from Halliday and Adler (2002).

\begin{tabular}{|c|c|c|c|c|}
\hline & No. species & $\%$ total & No. RAR+VER & $\% R A R+V E R$ \\
\hline \multicolumn{5}{|c|}{ Blind snakes (Scolecophidia) } \\
\hline Anomalepididae & 15 & 0.55 & 0 & 0 \\
\hline \multicolumn{5}{|l|}{ 'True snakes' (basal } \\
\hline \multicolumn{5}{|l|}{ Alethinophidia) } \\
\hline Typhlopidae & 215 & 7.91 & 6 & 2.91 \\
\hline Leptotyphlopidae & 90 & 3.31 & 5 & 2.43 \\
\hline Anomochilidae & 2 & 0.08 & 0 & 0 \\
\hline Uropeltidae & 45 & 1.65 & 0 & 0 \\
\hline Cylindrophiidae & 8 & 0.29 & 0 & 0 \\
\hline Aniliidae & 1 & 0.04 & 1 & 0.48 \\
\hline Xenopeltidae & 2 & 0.08 & 0 & 0 \\
\hline Loxocemidae & 1 & 0.04 & 0 & 0 \\
\hline Boidae & 28 & 1.03 & 5 & 2.43 \\
\hline Pythonidae & 25 & 0.92 & 3 & 1.46 \\
\hline Bolyeriidae & 2 & 0.08 & 0 & 0 \\
\hline Tropidophiidae & 21 & 0.77 & 0 & 0 \\
\hline \multicolumn{5}{|l|}{ 'Advanced snakes' } \\
\hline \multicolumn{5}{|l|}{ (Caenophidia) } \\
\hline Acrochordidae & 3 & 0.11 & 0 & 0 \\
\hline Colubridae & 1700 & 62.54 & 146 & 70.87 \\
\hline Viperidae & 230 & 8.46 & 15 & 7.28 \\
\hline Atractaspididae & 60 & 2.21 & 7 & 3.4 \\
\hline Elapidae & 270 & 9.93 & 18 & 8.74 \\
\hline TOTAL & 2718 & 100 & 206 & 100 \\
\hline
\end{tabular}


Therefore, I conclude that snake studies do not support the hypothesis of Cotgreave and Pavel (1997), which was based on a study of birds in Australia and therefore may well be valid for many other groups of animals.

\section{Conclusions}

This study has revealed noteworthy patterns associated with snake rarity worldwide. Some of these patterns previously have been highlighted in other organisms and are now confirmed with snakes, such as the positive correlation between total species number and the fraction of rare and very rare species, and the tendency of the fraction of rare species to increase in species-rich, tropical communities of snakes. Snakes also confirmed the theory that rarity is often associated with large body size, but with subtle differences from other animal types (i.e., very small species are also often rare in snake communities). I also demonstrated that snakes may be useful in testing whether species with narrower realized niches are more likely to be rare or very rare (as predicted by Gaston 1996 and Gaston and Curnutt 1998). This study, however, contradicts previous research on birds indicating that rare species are typically those that are phylogenetically primitive.

In general, my study reveals that snakes have the potential to become 'model organisms' for studies on the biology of rarity, and therefore I strongly urge other scientists to carry out further studies on the community ecology of snakes with an emphasis on rarity research. Further research should verify whether the patterns emerging from this study are in part due to statistical artefacts or are really true for snake communities worldwide.

Acknowledgments - This paper benefited from the critical review and English style revision by my friends and colleagues Lynne R. Baker (University of Minnesota, USA) and Dave Greenberg (University of California at Santa Barbara, USA), and anonymous referees. Its writing was financially supported by Demetra s.r.l., ENI S.p.a., and Conservation International Foundation through the Turtle Conservation Fund. I thank Godfrey C. Akani (University of Port Harcourt, Nigeria), Edem A. Eniang (University of Uyo, Nigeria), and Lorenzo Rugiero (F.I.Z.V., Roma) for much helpful discussion on 'rare species' and their general ecological characteristics.

\section{References}

Agrimi, U. and Luiselli, L. 1994. Ecology of the snake Coronella girondica (Reptilia: Colubridae) in central Italy. - Vie Milieu 44: 203-210.

Akani, G.C. et al. 1999. Snake communities of moist forest and derived savanna sites of Nigeria: Biodiversity patterns and conservation priorities. - Biodiv. Cons. 8: 629-642.

Akani, G.C. et al. 2002. Ecological patterns of anthropogenic mortality of suburban snakes in an African tropical region. Isr. J. Zool. 48: 1-11.
Andrén, C. and Nilson, G. 1983. Reproductive tactics in an island population of adders, Vipera berus (L.), with a fluctuating food resource. - Amphibia-Reptilia 4: 63-79.

Bersier, L.-F. and Sugihara, G. 1997. Species abundance patterns: the problem of testing stochastic models. - J. Anim. Ecol. 66: 769-774.

Blackburn, T.M. and Gaston, K.J. 1999. The relationship between animal abundance and body size in natural animal assemblages. - J. Anim. Ecol. 62: 519-528.

Block, W.M. and Morrison, M.L. 1998. Habitat relationships of amphibians and reptiles in California oak woodlands. - J. Herp. 32: 51-60.

Boundy, J. 2001. Herpetofaunal surveys in the Clark Fork Valley region, Montana. - Herpetol. Nat. Hist. 8: 15-26.

Branch, W.R. and Bauer, A.M. 1995. Herpetofauna of the Little Karoo, Western Cape, South Africa with notes on life history and taxonomy. - Herpetol. Nat. Hist. 3: 47-89.

Brown, W.S. and Parker, W.S. 1982. Niche dimensions and resource partitioning in a Great Basin Desert snake community. - In: Scott, N.J. Jr (ed.), Herpetological communities. United States Dept of the Interior, pp. 59-81.

Bruno, S. and Maugeri, S. 1990. Serpenti d'Italia e d'Europa. Edit. Giorgio Mondatori, Milano.

Butler, J.A. and Reid, J. 1986. Habitat preferences of snakes in the Southern Cross River State, Nigeria. - In: Rocek, Z. (ed.), Studies in Herpetology. Charles University Prague, pp. 483-488.

Capizzi, D. et al. 1995. Feeding habits of a Mediterranean community of snakes in relation to prey availability. - Rev. Ecol. (Terre et Vie) 50: 353-363.

Cavitt, J.F. 2000. Fire and a tallgrass prairie reptile community: effects on relative abundance and seasonal activity. - J. Herp. 34: 12-20.

Chippaux, J.-P. 1999. Les serpents d' Afrique occidentale et centrale. - IRD Editions, Paris.

Cotgreave, P. 1993. The relationship between body size and population abundance in animals. - TREE 8: 244-248.

Cotgreave, P. and Pagel, M.D. 1997. Predicting and understanding rarity: the comparative approach. - In: The biology of rarity, Kunin, W.E. and Gaston, K.J., eds, pp. 237-261. Chapman \& Hall, London.

Da Silva, J. 1993. The snakes from Samuel Hydroelectric Power Plant and vicinity, Rondonia, Brazil. - Herpetol. Nat. Hist. 1: 37-86.

Duellmann, W.E. 2005. Cusco Amazonico: the lives of amphibians and reptiles in an Amazonian rainforest. - Cornell Univ. Press, Ithaca NY.

Enge, K.M. and Wood, K.N. 2000. A herpetofaunal survey of Chassahowitzka Wildlife Management Area, Hernando County, Florida. - Herpetol. Nat. Hist. 7: 117-144.

Eniang, E.A. et al. 2002. On the composition of the snake fauna of Uyo, a recently deforested area in Nigeria. - Herpetozoa 14: 143-147.

Filippi, E. 1995. Aspetti dell'ecologia di due comunità di Colubridi e Viperidi (Reptilia, Serpentes) di un'area dell' Italia centrale (Monti della Tolfa, Lazio). - Unpubl. PhD Thesis, Univ. of Rome 'La Sapienza'.

Filippi, E. 2003. The effects of timbering on a snake community of a Mediterranean area of central Italy. - Amphibia-Reptilia 24: 75-79.

Filippi, E. and Luiselli, L. 2000. Studi sulle comunità di serpenti della riserva parziale 'Montagne della Duchessa'. Ecologia del 
popolamento e conseguenze gestionali, con speciale riferimento a Vipera ursinii ursinii. - Technical Report, Duchessa Mountains Natural Park, pp. 1-58.

Filippi, E. and Luiselli, L. 2006. Changes in community composition, habitats and abundance of snakes after $10+$ years in a protected area in Italy: conservation implications. - Herp. J. 16: 29-36.

Fitch, H.S. 1982. Resources of a snake community in prairiewoodland habitat of northeastern Kansas. - In: Scott, N.J.Jr (ed.), Herpetological communities. United States Dept of the Interior, pp. 83-97.

Fitch, H.S. 1999. A Kansas snake community: composition and changes over 50 years. - Krieger.

Fleet, R.R. and Autrey, B.C. 1999. Herpetofaunal assemblages of four forest types from the Caddo Lake area of northeastern Texas. - Texas J. Sci. 51: 297-308.

Ford, N.B. et al. 1991. Species diversity and seasonal abundance of snakes in a mixed pine-hardwood forest of eastern Texas. Southwest. Nat. 36: 171-177.

Gaston, K.J. 1994. Rarity. - Chapman \& Hall, London.

Gaston, K.J. 1996. The multiple forms of the interspecific abundance-distribution relationship. - Oikos 76: 211-220.

Gaston, K.J. and Curnutt, J.L. 1998. The dynamics of abundance-range size relationships. - Oikos 81: 38-44.

Gibbons et al. 1997. Perceptions of species abundance, distribution, and diversity: lessons from four decades of sampling on a government-managed reserve. - Environ. Manag. 21: 259-268.

Greene, H.W. 2001. Snakes: the evolution of mystery in nature. - California Univ. Press.

Halliday, T. and Adler, K. 2002. The new encyclopedia of reptiles and amphibians. - Oxford Univ. Press.

Harcourt, A.H. et al. 2002. Rarity, speciation and extinction in primates. - J. Biogeogr. 29: 445-456.

Hughes, R.G. 1986. Theories and models of species abundance. - Am. Nat. 128:879-899.

Inyang, M.-A. 2005. Food habits and ecology of arboreal snake populations in southern Nigeria. - Unpubl. diss., Environ. Stud. Centre Demetra.

Johansson, F. et al. 2006. Species abundance models and patterns in dragonfly communities: effects of fish predators. - Oikos 114: 27-36.

Kunin, W.E. and Gaston, K.J. (Eds). 1997. The biology of rarity. - Chapman \& Hall, London.

Lee, T.H. 2005. Ecological patterns of distribution on gradients of elevation and species diversity of snakes in southern Taiwan. - Amphibia-Reptilia 26: 325-332.

Lewis, S.D. et al. 2000. Herpetofaunal assemblages of four forest types in the Big Sandy Creek Unit of the Big Thicket National Preserve. - Texas J. Sci. 52: 139-150.

Luiselli, L. 2006a. Broad geographic, taxonomic and ecological patterns of interpopulation variation in the dietary habits of snakes. - Web Ecol. 6: 2-16.

Luiselli, L. 2006b. Resource partitioning and interspecific competition in snakes: the search for general geographic and guild patterns. - Oikos 114: 193-211.

Luiselli, L. 2006c. Site occupancy and density of sympatric Gaboon viper (Bitis gabonica) and nose-horned viper (Bitis nasicornis). - J. Trop. Ecol. 22: 555-564.

Luiselli, L. and Akani, G.C. 2002. An investigation into the composition, complexity and functioning of snake communities in the mangroves of south-eastern Nigeria. - Afr. J. Ecol. 40: 220-227.
Luiselli, L. et al. 1998. Food resource partitioning of a community of snakes in a swamp rainforest of south-eastern Nigeria. J. Zool. London 246: 125-133.

Luiselli, L. et al. 2005. Relationships between body size, population abundance and niche characteristics in the communities of snakes from three habitats in southern Nigeria. - J. Zool. London 265: 207-213.

Marques, O.A.V. et al. 2001. Seasonal activity of snakes in the Atlantic forest in southeastern Brazil. - Amphibia-Reptilia 22: 103-111.

McDonald, L.L. and Thompson, W.L. 2004. Sampling rare populations. - Island Press, Washington D.C.

Morse, D.R. et al. 1988. Species number, species abundance and body length relationships of arboreal beetles in Bornean lowland rainforest trees. - Ecol. Entomol. 13: 25-37.

Moulliot, D. et al. 2000. The fractal model: a new model to describe the species accumulation process and relative abundance distribution (RAD). - Oikos 90: 333342.

Novotny, V. 1993. Spatial and temporal components of species diversity in Auchenorrhyncha (Insecta: Hemiptera) communities of Indochinese montane rain forest. - J. Trop. Ecol. 9: 93-100.

Novotny, V. and Basset, Y. 2000. Rare species in communities of tropical insect herbivores: pondering the mystery of singletons. - Oikos 89: 564-572.

Price, P.W. et al. 1995. The abundance of insect herbivore species in the tropics: the high local richness of rare species. - Biotropica 27: 468-478.

Rabinowitz, D. 1981. Seven form of rarity. - In: The biological aspects of rare plant conservation, Synge, H., Ed. Pp. 205217, Wiley.

Reynolds, R.P. and Scott, N.J. Jr. 1982. Use of a mammalian resource by a Chihuahuan snake community. - In: Scott, N.J.Jr (ed.), Herpetological communities. United States Dept of the Interior, pp. 99-118.

Rugiero, L. 2004. Composition of the reptile communities in five urban protected areas of different isolation degrees. Herpetozoa 16: 151-155.

Schmidt, W.R. and Olsen, P. 1998. Using the road as a means of conducting herpetological surveys: an example from warmbaths. - Afr. Herp. News 28: 24-26.

Schoener, T.W. 1987. The geographical distribution of rarity. Oecologia 74: 161-173.

Seigel, R.A. et al. 1995. Temporal changes in reptile populations: effects of a severe drought on aquatic snakes. - Herpetologica 51: 424-434.

Shine, R. 1977. Habitats, diets, and sympatry in snakes: a study from Australia. - Can. J. Zool. 55: 1118-1128.

Shine, R. 1980. Reproduction, feeding and growth in the Australian burrowing snake Vermicella annulata. - J. Herp. 14: 71-77.

Shine, R. 1984. Reproductive biology and food habits of the Australian elapid snakes of the genus Cryptophis. - J. Herp. 18: 33-39.

Shine, R. 1993. Australian snakes: a natural history. - Reed Books, Sydney.

Shine, R. and Bonnet, X. 2000. Snakes: a new 'model organism' in ecological research? - TREE 15: 221-222.

Shine, R. et al. 1996. Sexual dimorphism, reproductive biology, and food habits of two species of African filesnakes (Mehelya, Colubridae). - J. Zool. London 240: 327-340. 
Shine, R. et al. 2006. Biology of burrowing asps (Atractaspididae) from southern Africa. - Copeia 2006: 103-115.

Spencer, M. 2000. Are predators rare? - Oikos 89: 115-122.

Stork, N.E. et al. 1997. Canopy arthropods. - Chapman \& Hall, New York.

Tokeshi, M. 1990. Niche apportionment or random assortment: species abundance patterns revisited. - J. Anim. Ecol. 59: 1129-1146.

Tokeshi, M. 1996. Power fraction: a new explanation of relative abundance patterns in species rich environments. - Oikos 75: 543-550.

Trape, J.-F. and Mane, Y. 2000. Les serpents des environs de Dielmo (Sine-Saloum, Sénégal). - Bull. Soc. Herp. Fr. 95: 1935.
Ulrich, W. 2001a. Ecological characteristics of rare species : the case of parasitic Hymenoptera. - Pol. J. Ecol. 49: 379-389.

Ulrich, W. 2001b. Relative abundance distributions of species : the need to have a new look at them. - Pol. J. Ecol. 49: 391405.

Vandermeer, J. 1982. To be rare is to be chaotic. - Ecology 63: 1167-1168.

Wilcove et al. 1998. Quantifying threats to imperiled species in the United States. - Bioscience 48: 607-615

Yanosky, A.A. et al. 1996. Ecology of the snake community at El Bagual Ecological Reserve, Northeastern Argentina. - Herpetol. Nat. Hist. 4: 97-110.

Yu, J. and Dobson, F.S. 2000. Seven forms of rarity in mammals. - J. Biogeogr. 27: 131-139. 
Appendix 1. Raw list of rare (RAR) and very rare (VER) species by study area, including the pertinent literature entry.

\begin{tabular}{|c|c|c|}
\hline Study area (reference) & list of RAR species & list of VER species \\
\hline $\begin{array}{l}\text { Monterano } \\
\text { (Filippi and Luiselli 2006) }\end{array}$ & Coronella austriaca & Coronella girondica \\
\hline $\begin{array}{l}\text { Eket } \\
\text { (Luiselli et al. 2005) }\end{array}$ & $\begin{array}{l}\text { Crotaphopeltis hotamboeia; Mehelya } \\
\text { crossii;Aparallactus } \\
\text { modestus;Dasypeltis fasciata;Naja } \\
\text { melanoleuca }\end{array}$ & $\begin{array}{l}\text { Dipsadoboa duchesnii;Lamprophis } \\
\text { virgatus;Mehelya poensis }\end{array}$ \\
\hline $\begin{array}{l}\text { Port Harcourt } \\
\text { (Luiselli and Akani 2002) }\end{array}$ & Philothamnus nitidus; Naja melanoleuca & Dendroaspis jamesoni \\
\hline Ejule & Dipsadoboa duchesnii; Dasypeltis & \\
\hline (Ákani et al. 1999) & fasciata; Atractaspis aterrima & \\
\hline Tengchih (Lee 2005) & $\begin{array}{l}\text { Elaphe porphyracea; Elaphe taeniura; } \\
\text { Oligodon ornatus }\end{array}$ & \\
\hline $\begin{array}{l}\text { Big Sandy Creek } \\
\text { (Lewis et al. 2000) }\end{array}$ & Heterodon platirhinos & \\
\hline $\begin{array}{l}\text { Sheff's Wood } \\
\text { (Ford et al. 1991) } \\
\text { Caddo Lake } \\
\text { (Fleet and Audrey 1999) }\end{array}$ & $\begin{array}{l}\text { Farancia abacura; Heterodon nasicus; } \\
\text { Regina rigida } \\
\text { Farancia abacura; Nerodia } \\
\text { rhombifera; Regina rigida }\end{array}$ & Coluber constrictor; Nerodia fasciata \\
\hline
\end{tabular}

(Capizzi et al. 1995)

Sella Nevea

(Luiselli 2006)

Kansas (Fitch 1982)

Chihuahua

(Reynolds et al. 1982)

Elaphe guttata, Masticophis taeniatus

Dielmo

(Trape and Mane 2000)

Python sebae, Python

regius, Lamprophis

fuliginosus, Philothamnus irregularis, Dromophis lineatus, Atractaspis micropholis, Naja katiensis

Nerodia sipedon; Lampropeltis calligaster; Lampropeltis triangulum; Pituophis melanoleucus;

Storeria dekayi; Crotalus horridus

Crotalus lepidus, Heterodon nasicus, Thamnophis cyrtopsis, Trimorphodon biscutatus, Tantilla nigriceps, Salvadora deserticola, Sonora semiannulata

Typhlops lineolatus, Leptotyphlops boueti, Philothamnus semivariegatus, Prosymna meleagris, Grayia tholloni, Crotaphopeltis hotamboeia, Dromophis praeornatus, Dasypeltis scabra, Dasypeltis fasciata, Atractaspis microlepidota, Amblyodipsas unicolor, Naja melanoleuca, Naja nigricollis, Elapsoidea semiannulata, Bitis arietans

Duchessa Mt

(Filippi and Luiselli 2000)

Rota (Filippi 1995)

Calabar

(Butler and Reid 1986)

Mehelya guirali, Lamprophis virgatum, Dipsadoboa duchesnii, Crotaphopeltis hotamboeia, Naja melanoleuca
Typhlops punctatus, Natriciteres variegata, Natriciteres fuliginoides, Lamprophis olivaceum, Philothamnus heterodermus, Gastropixys smaragdina, Thrasops flavigularis, Thelotornis kirtlandii, Polemon collaris, Aparallactus modestus, Pseudohaje goldii, Causus maculatus, Atractaspis corpulenta
Clark Fork Valley

(Boundy 2001)

Little Karoo

(Branch and Bauer 1995)
Amplorhinus multimaculatus,

Dispholidus typus,

Naja nivea, Bitis arietans, 
Rondonia

(da Silva 1993)

Oriolo Romano

(Luiselli et al. Unpubl.)

Rome (Rugiero 2004)

El Bagual

(Yanosky et al. 1996)

Hernando

(Enge and Wood 2000)

Great Basin Desert

(Brown and Parker 1982)

Armidale (Shine 1977)

Cusco Amazzonico

(Duellmann 2005)

Cotonou (Inyang 2005)

Lekki Lagoon

(Inyang 2005)

Uyo (Eniang et al. 2002)

Yenagoa

(Akani et al. 2002)
Typhlops reticulatus, Corallus enydris, Epicrates cenchria, Atractus insipidus, Dendrophidion dendrophis, Oxyropus melanogenys, Drepanoides anomalus, Tripanurgos compressus, Xenopholis scalaris, Bothrops brasili

Coronella austriaca

Eunectes notaeus

Elaphe guttata, Regina alleni, Seminatrix pygaea, Thamnophis sirtalis

Lachesis muta, Chironius scurrulus, Bothrops atrox, Drimobius rhombifer, Leptophis aethulla, Oxyrhopus petola, Drepanoides anomalus, Dipsas indica, Siphlophis cervinus, Taeniophallus occipitalis, Tantilla melanocephala

Boiga pulverulenta, Thrasops jacksoni, Naja melanoleuca

Boiga pulverulenta

Lamprophis lineatus, Thrasops flavigularis, Thrasops occidentalis, Natriciteres fuliginoides, Aparallactus modestus, Dendroaspis jamesoni, Bitis gabonica Dendroaspis jamesoni, Causus maculatus
Leptotyphlops macrolepis, Leptotyphlops septemstriatus, Anilius scytale, Corallus caninus, Apostolepis quinquelineata, Atractus albuquerquei, Brachyorrhos flammigerus, Atractus latifrons, Atractus flammigeus, Atractus taeniatus, Chironius exoletus, Chironius fuscus, Chironius multiventris, Chironius scurrulus, Clelia clelia, Dipsas catesbyi, Dipsas indica, Drymarchon chorais, Drymoluber dichrous, Echinantera brevirostris, Echinantera occipitalis, Helicops hagmanni, Helicops polylepis, Imantodes cenchroa, Imantodes lentiferus, Leptophis aethulla, Liophis poecilogyrus, Liophis typhlus, Mastigodryas boggaerti, Ninia hudsoni, Oxybelis aeneus, Oxybelis argenteus, Oxyrhopus formosus, Oxyropus occipitalis, Oxyrhopus petola, Philodryas viridissima, Pseudoboa coronata, Pseustes poecilinotus, Pseutes sulphureus, Siplophis cervinus, Siplophis worontzowi, Spilotes pullatus, Tantilla melanocephala, Xenodon rabdocephalus, Xenodon severus, Micrurus lemniscatus, Bothriopsis taeniata, Porthidium hyoprora, Lachesis muta Elaphe quatuorlineata

Atractus reticulatus, Clelia rustica, Chironius quadricarinatus, Hydrodynastes gigas, Liophis flavifrenatus, Oxyrhopus guibei, Oxyrhopus rhombifer, Philodryas aestivus, Philodryas olfersi, Psomophis obtusus, Taeniophallus occipitalis, Thamnodynastes sp. 2

Agkistrodon piscivorus, Crotalus adamanteus, Drymarchon corais, Heterodon simus, Lampropeltis triangulum, Nerodia floridana, Pituophis melanoleucus, Tantilla relicta, Sistrurus miliaris

Diadophis punctatus

Cryptophis nigrescens, Vermicella annulata Eunectes murinus, Drymarchon corais, Pseustes sulphureus, Pseudoeryx plicatilis, Xenodon severus, Micrurus surinamensis, Helicops angulatus, Liophis typhlus, Anilius scytale, Oxyrhopus petolarius, Pseudoboa coronata, Oxybelis aeneus, Micrurus annellatus, Oxyrhopus formosus, Helicops polylepis, Atractus flammigerus, Liophis taeniogaster, Leptotyphlops diaplocius

Causus lichtensteini, Pseudohaje goldii, Pseudohaje nigra

Causus lichtensteini, Pseudohaje goldii, Naja melanoleuca

Crotaphopeltis hotamboeia, Atractaspis corpulenta, Typhlops congestus 
Sierra Nevada

(Block and Morrison 1998)

Konza Prairie (Cavitt 2000)

Elaphe obsoleta

Tolfa Mt (Filippi 2003)

Mabula-Rojberg

(Schmidt and Olsen 1998)

Langjan (Schmidt 2002)
Python natalensis, Aparallactus capensis, Telescopus semiannulatus, Atractaspis duerdeni, Xenocalamus bicolor, Prosymna bivittata, Causus defilippii, Pseudaspis cana Prosymna bivittata, Psammophis brevirostris, Dispholidus typus, Elapsoidea sundevallii, Dendroaspis polylepis
Tropidoclonion lineatum, Lampropeltis calligaster, Storeria dekayi

Natrix natrix

Rhinotyphlops lalandei, Amblyodipsas polylepis, Lycophidion capense, Thelotornis capensis, Psammophis subtaeniatus, Psammophylax tritaeniatus, Aspidelaps scutatus, Dendroaspis polylepis, Bitis caudalis

Rhinotyphlops lalandei, Leptotyphlops longicaudatus, Dasypeltis scabra, Naja mossambica 